\title{
Time Logic on the Move
}

\author{
Kuangming Wu \\ Philosophy Department, University of Wisconsin-Oshkosh, Oshkosh, Wisconsin, USA \\ Email: kmwu2002@yahoo.com
}

How to cite this paper: $\mathrm{Wu}, \mathrm{K} . \mathrm{M}$. (2017) Time Logic on the Move. Open Journal of Philosophy, 7, 231-248.

https://doi.org/10.4236/ojpp.2017.73014

Received: April 26, 2017

Accepted: July 11, 2017

Published: July 14, 2017

Copyright (C) 2017 by author and Scientific Research Publishing Inc. This work is licensed under the Creative Commons Attribution International License (CC BY 4.0).

http://creativecommons.org/licenses/by/4.0/

\begin{abstract}
Things exist logically as understandable through time; such logic is called "time logic" that includes both logically dead and alive. This essay features time logic on the move, personal concrete, coherent open, and inter-changing into music.
\end{abstract}

\section{Keywords}

Logic, Time, Alive, Move

We daily plan, schedule, and engage in business as we constantly consult with calendar. Three points show here. One, our engagement shows time. Two, timeactivity makes sense, and so time is time logic. Three, time logic is on the move. Seemingly, such time logic on the move peculiarly differs from usual logic. Usual logic never moves, never engages, and has no time. Time logic on the move is no usual logic at all.

This important point is worth repeating. Time logic constantly moves on as time moves. Time is sensible. Logic is of course sensible. And so, time is by nature time logic. Oddly, in contrast, usual logic never moves, as it has no time. Usual logic in unmoving way considers moving time as its object to think about. Unmoving usual logic slaps on "time" an odd phrase "moving image of eternity" quite senselessly. But time is not an object, and so time is not even thinkable in usual logic.

All this while, time logic keeps moving on. It is the very nature of time logic to be on the move. In fact, time logic is behind usual logic to sire usual logic, as abstract usual logic is abstracted from universal time. And so, time logic sires usual logic to easier handle matters now not moving. We are now aware that logic is of two kinds. This essay elucidates time logic on the move, by adumbrating it, because time logic is so vast and impossible to exhaustively explain.

In addition, things also exist logically as understandable. Logic of existence 
continues variously through time, to call "time logic" inclusive of both usual static logic and alive. This essay features time logic on the move, personal and concrete, coherent open-ended, and inter-changing into music. Time logic begins as a person. The person is composed of interactivities since birth, which is reasonable through time of living days. Persons are time-related logic, surrounded by existence as symbiotic interacting. All existence is thus time logic on the move. Such time logic sires usual logic.

Usual logic is dead-set; time does not exist in usual logic that is eternal. Eternity is perfect reality; actuality is its flickering shadow. Plato saw such idea of logic; vision (idein) is idea (Merriam-Webster's Collegiate Dictionary, 2008). Significantly, he "imagined" his idea-vision as myth or "parable" of the cave. "Imagined" and "parable" appear in Plato's Republic 514a (Plato, 1941; 2008). Its details will soon appear below. Still, rarely do later thinkers realize that there exists another sort of logic intimately involved with time, called "time logic", without which usual logic turns constitutively defective. Now, this is quite a serious indictment, in need of explanation. A devastating example is here at hand.

The philosophically crucial notion of "mistake" would be all-missed without time logic, for it is part of time-logic. "Mistake" means missing taking something as that "something". Mistake takes something amiss as something else. As such, mistake is inherently timely. Missed-taking is verified only subsequently in time.

Mistake is realized only later in time, and so it is impossible to purposely plan to commit in the future. Thus mistake is retrospective. I belatedly find that I have taken something amiss only after I have done my deed. No one would plan to take-amiss anything. I would not pursue making mistakes as my future purpose. Mistake makes sense only in terms of time logic.

This time-logical point of mistake is totally missed in usual logic that has no time. And so usual logic vainly speculates timeless possibilities of error such as "ignorance" (Socrates), "mis-picking memories" (Plato), "excess of will" (Descartes), "implying perfect knowledge" (Royce) (Reese, 1999: pp. 208-209). They either just push the problem back further (why ignorant or mis-picking?) or are irrelevant (will and assumption are irrelevant). Such logical fumbling originates in the lack of time logic in usual logic.

Usual logic is not aware that it has another sort of logic, "time logic", behind it and including it, this way. Mathematics is how usual logic operates. Observant Kant (2007) said, "7 $+5=12$ " is an operation of "synthetic a priori", because "12" cannot be deduced from " 7 " or " 5 " but must be added with 7 and 5 to obtain, and adding is "synthetic", yet this synthesis is logically necessary, and so $7+$ $5=12$ is "a priori". So, mathematics operated in usual logic is a synthetic a priori operation. "Synthetic" is open and timed; "a priori" is coherent and logical. Mathematics as synthetic a priori is time logic open and coherent through time. Mathematics is time logic.

Time logic is alive and concrete as time constantly moving. Usual logic takes place in time; time logic enables usual logic to exist timeless. Time also enables time-stopping ecstasy of creativity, to yield time-stopping beauty chanting the 
world on and on. The chanting performs music that is the supreme logic of time that enables such time-stopping music to chant time. Enablement creates; creation is divine. So, time logic is divine. This theme will be elaborated later.

Time logic blends time into logic as timed logic, timely logic, time as logic, and logic as time, and so on; any one of them involves all others. We can easily see that such time logic is never dead-set but ever variously alive, constantly on the move. Naturally, time logic concrete alive is astoundingly numerous and unexpected; its features are well-nigh inexhaustible, all peculiar and essential to living actuality. The following pages manage to adumbrate some of its outstanding features.

Time-moving shows how things concrete are on the go; undergoing time presents things concrete that in turn describes time undergoing. Things concrete have their own logic that is time logic here now concretely. The renowned Classic of Changes 易經 combines poetry and mathematics to involve all things to compose time logic. Poetry is concrete and timely, and mathematics is poetic logic of time.

Such concrete time is packed and expressed as "time logic" as logic concrete, the concrete logicized, all timely on the move. Time is concretely logical; logic is timely moving on. All things are concretely in change, expected logically, yet surprisingly timely. Nothing is out of time, as its logic is ever moving on to and fro in time. Time logic is chock-full of astounding features. Here are some so noticeable.

\section{Indispensable Ubiquitously}

To begin, thinking logically makes us human beyond being exclusively animals. Thinking takes place in time. Abstract analysis is part of "time logic". In fact, all thinking logically is time logic. This ubiquity is the first peculiar feature of time logic. Unmoving eternity forever haunts time ever moving. Plato frivolously contrives the Myth of the Cave for the eternal realm of sunny idea-forms, fully knowing that such myth-concoction is just an allegory made in time as Plato thinks on timely. This myth or allegory appears in Plato's Republic (Plato, 1941: pp. 227-235).

In fact, the Myth of the Cave exemplifies all Plato's myths as on matters unmoving eternal, forever hovering over moving time (Stewart \& Levy, 1960). Introductions pathetically struggle to show how myths relate to thinking reality, as if to take myths as part of reality. Let myths be myths! This clear-cut distinction is the basic requirement of responsible thinking. In order to think at all, we must distinguish hovering eternity we concoct from our own toddling thinking ever on the uncertain way in concrete time. In this sense, ubiquitous time logic requires personal honesty.

Sadly, Plato's thoughtful honesty is lost in later philosophers in the West, who confuse their concoction of myths with outside reality they pursue. In fact, they are even unwilling to distinguish, as they stubbornly determine to confuse their concoction with reality-by relying on "deduction" that is their own concoction! 
They stubbornly dream on their own dreams, refusing ever to wake up. Such hubris makes an Icarus (1991) who drowns in the concrete sea of concrete time! Icarus flew too close o the sun and had his wax-wings melted to fall into the sea and drowned. Flying too close to the sun is taken here as hubris.

Thinking realizes that nothing in life is perfect. Logic-as-time ongoing inevitably sees the past as wrong so as to pursue its correction now. Likewise, logic sees "you" as wrong, and pursues "me" to correct you. "Philosophy" is the name of such inter-critical process. Criticism is logic; process is time. The process of criticism is time logic in history. "History" is such critical philosophy in time, to compose time logic. History is time logic ubiquitous. Honest Plato is smiling here.

Never staying put, the ubiquity of time logic constantly moves onward, from the primordial origination of all things through all time to their ultimate culmination forever unreachable. Such ubiquitous process of time logic is vividly named-as the essence of things-"God" the Alpha and the Omega through time as Emmanuel God-with-us, through thick and thin, no matter what. Godbeyond-human is ubiquitously hovering over all things and each human person in all cosmic time ubiquitous and personal.

What stuns us in all this cosmic drama is that this almighty all-ubiquitous Immanuel, God-with-us, is the name of a totally helpless baby; the baby is God en-fleshed, entrusted to us human persons, personally as his parents to meticulously care for and assiduously raise as "Jesus" who is, believe it or not, our Savior. We human parents care for and raise our Savior entrusted to us by God-with-us Immanuel! Such stunning divine-human symbiosis as the Incarnation describes time logic, graphically ubiquitous and concretely personal and dynamic.

All this symbiosis begins at every moment when almighty God-with-us is born into a human baby all-helpless, entrusted into our personal caring hands. We do parental cares for the helpless baby who is God-en-fleshed into each of us! And human babies are all over ubiquitously among us. Each neighbor is a baby to us, and they are our God entrusted to us to care for!

Such is our personal caring responsibility ubiquitous each time we meet our neighbors. We despair and mumble "too much is too much". Knowing all this, God-with-us continues to support us as His babies to enable us to fulfill our caring responsibilities for all "babies" we meet in our neighbors-who are our God entrusted to our parental caring absolutely personal!

So, God-with-us as a helpless human baby, my divine babies as my neighbors, and God our baby helping us on who are his babies, these three points stun me in God-with-us born at Christmas each day. All these divine-human baby-happenings in time boggle our mind and move us heartfelt. Such is the ubiquity of time logic that spells our personal responsibilities to care for those we meet as our "babies" who are our God.

The New Testament-God's new contract with us human persons-begins as "Baby Immanuel" just given us outright without condition. In Immanuel God- 
with-us, "with" is the four-lettered baby-pivot so tender that unites God to us. God is our baby, and we are God's babies as our neighbors are our babies. The baby is helpless, the baby is our God, and so God almighty is helpless. All these are surprises centered on the baby so precious, who spells "tender loving care" holy and unavoidable. This divinity warmly embraces each of us personally, who is, again, God's precious baby. Each day, "Christmas" bundles up all these tender loving surprises.

It is thus that ubiquity of time logic bespeaks personal caring. The baby "Jesus", meaning Yehoshuah "Yahweh is salvation" (cf. Matthew 1:21) (Buttrich, 1962), is the focal unity of ubiquity with personal specificity. This unity is what saves us in person ubiquitously. This is one of many stunning features of Godwith-us to be our human baby. This "ubiquity as personal" is an additional feature of time logic, to which we now turn.

\section{Personal}

For all its vast cosmic ubiquity, however, time has no time-in-general. Time ubiquitous is intensely personal. We all personally breathe time to live on. As no one breathes breaths-in-general, so no one lives in time-in-general. Time is peculiar this way, to wit, time combines this "all"-ubiquity with this "each" the personal. Time ubiquitous is time ubiquitously personal. Ubiquity of time deepens personal-depths of time.

Time always facilitates personal encounters, some more personable than others, and these personal meetings are always more or less unexpected and surprising. Time always brings the personal to us. Time has nothing indifferent. Time has nothing that is impersonal. Even the casual tick-tocking of a clock brings to Haydn his intimate "Clock Symphony”. Every natural moment inspires musical composition intensely personal, as "repeated chores" produce popular songs to hum along.

As time brings us the personal, time brings us beyond us-now. The tomorrow is invariably more significant, if not better, than today. Natural science is built on this hope of the better and richer future. Even the tomorrow of execution gave Boethius the world's bestseller and longest seller, the "Consolation of Philosophy". Even the horrendous death-ovens in Auschwitz brought Frankl the diehard his stubborn "Logotherapy" that is the dare-devil shouting "never say die!" (Howatson, 1991; Frankl, 1984).

As long as we are alert and aware, time is seen to always bring us invincible hope alive, no matter what, to pulse us ahead out of hopeless despair-dehope-here now. Søren Kierkegaard rightly called despair in hopelessness "sickness unto death". Sadly, however, Kierkegaard missed this sickness as timely, sooner or later to pass into new tomorrow of new hope. In all, time-ubiquitous ubiquitously brings to each of us the personal, the better, the beyond-now, and so the hope, and such bringing constitutes time logic. Time logic is forever personally hopeful.

Related to time having no time-in-general, we have no "philosophy of philos- 
ophy", nor do we have "philosophy of history". Philosophizing on philosophy is another philosophy; thinking about history is itself history. We have no superphilosophy or super-history on top of usual philosophy or usual history. To go beyond here is just to add one more of the same.

This is simply because, among others, the much-promoted "self-criticism" is actually impossible, for one's self is invisible to oneself. What we refer as "you" and "I" are really ideas projected on the invisible screen of the self, and projection is time logic on the move. "You" and "I" are themselves time-logic in the concrete. This point leads us to the next feature of time logic, the concrete. It is also peculiar to time logic.

\section{Concrete}

In addition, time logic is amazingly concrete. We would never have expected that logic ubiquitous is concrete. Isn't logic supposed to be not-concrete? But "concrete" is by nature in time never arbitrary, and time logic is inherently concrete. Usual logic is constitutively defective without concrete time logic. "Mistake" was cited above as an example of how defective timeless usual logic is. Here is an additional telling example. Whitehead the master logician-in usual logic-blasted the usual logic of " $1+1=2$ " by a concrete case of one spark plus one explosive-load to produce much more than two splinter pieces.

And then he, based on this concrete blast, concludes by quipping, "The exactness is a fake" (Schilpp, 1951). This anti-logic logical quip out of a master logician was his last public statement. Sadly, he logically realized the defect of usual logic, not time logic behind it that corrects it (Schilpp, 1991). This blast on usual logic is his last public pronouncement as the master of usual logic. "Exactness" is prided by usual logic, and it is blasted by the explosive concrete example sensible in common sense. Whitehead the usual logician instinctively appealed to "common sense" to blast usual logic, and common sense routinely operates in concrete time logic.

Now, let us go a positive way. Marcel noted that naming Thou turns Thou into an It, as the personal Thou is designated by an indifferent name "Thou". Buber responded that Thou met and addressed stays Thou (Friedman \& Schilpp, 1957). Actually both are correct, depending on how I relate to an entity, naming it or addressing it. I can take an indifferent stone either as part of an indifferent landscape, or else I can cherish this stone as my indispensable support, as a Thou. It-stone is no Thou-stone, but this same stone can be either a personal Thou-stone or an indifferent It-stone. By the same token, Kant says that my personal two hands, right and left, determine east and west, to determine the entire world (Spicker, 1970). The world appears through my intimate two hands indifferently stretched far. "Far" as an It can be addressed as a motherly Thou, when our primal Zulu friends say that "far" is "there where someone wails, 'O mother, I am lost!'” (Buber, 1958). All such space-time interrelations, as an It and as a Thou, constitute the time logic concrete and alive.

But being concrete is more difficult than we expect. "Cannot bear, and bear, is 
to bear", says Japan on forbearance, echoed by Confucius 3/1, "This I can forbear, what can I not forbear?" But it is a struggle in concrete living to bear the unbearable, and its easy failure immediately harvests widespread explosions of tragedies, as graphically shown by the gripping tragedy of Chushingura 忠臣藏. If we do succeed in bearing the unbearable, however, no one is exploded, and this forbearance will keep me intact together and not exploding others-and so all of us are kept intact together concretely. Keeping-intact together spells the concrete, all too concrete.

So many people are "cold-blooded animals"; they freeze me. I keep me distant. This keeping is also forbearing. It is thus that resolute holding back tightly to oneself is concretely non-arbitrary, and such hold-back composes the struggling integrity of a person, bearing up the Heavens, packing firm the Earth. This is the cosmic "courage to be", which is the true virtue and concrete manliness, to concretize beings. This striking phrase is Tillich's. Sadly, he tends to be vague and undefined (Tillich, 1968). Logic-in-time and logic-as-time as concrete must now be elucidated; it is a big crucial theme.

Cohering concretizes, to wit, cohering as sticking-together makes things to concretely appear as themselves. Now we must see how entities sticking-together grow-together in "concrescence"-to grow together in concrescence to turn concrete-into a concrete thing, one after another.

The concrete is not a static description of static things; the concrete is instead a struggling verb that enlivens days, one day at a time. We are children bubbling up constantly with dreams that are our myths. We grab such concocted myths that pull us ahead to concretize them to create our selves concretely. We call these myths our "plans". We struggle to concretize our plans into concrete actuality of our self.

But upon being confronted with concrete actuality we have created, we cringe into dissatisfaction. We are then provoked into creating more new dreams that are our new myths our new plans. Constantly dissatisfied, we keep creating new myths to keep struggling ahead. Doesn't this dissatisfaction concretely describe our concrete days?

Thus it is that myths and their concretizations, concretized actuality and then more new myths, constantly inter-involve, constantly inter-creating to inter-concretize. Such constant inter-dynamics is our eternity that forever creates myths to concretize actuality on and on. Never staying put, eternity moves on to pull us forward, forever enmeshed in our concrete actualizations to constitute our days, common and concrete, and ever moving ahead. To concretize is to gather together into concrete existence. Such is time logic on the move concretely.

Now let us be clear about togetherness so rich and fascinating; it consists in two qualities, distinguishable and inseparable. Concrete things are all distinguishable and inseparable. All existence is made possible by distinction that yet cannot be separated. Confusing the two-taking distinguishable as separable, taking distinction as division to divide things-divides and separates an entity into pieces, and existence no longer obtains. Separation alone kills existence. 
Taking distinction as separation commits homicide and thing-cide. Distinction alone kills togetherness to kill things.

In contrast, togetherness is distinguishable-and-inseparable. Togetherness is based on, first, all elements as distinguishable; without each element as distinct, togetherness is impossible. At the same time, secondly, such distinction enables inseparable gathering to compose and constitute things concrete. Now, com-posing (posing together), con-stituting (stand-together), and con-cretizing (concrescence growing-together) are three synonyms for togetherness that, to repeat, sires concrete existence whatever. Togetherness is the unique mother of all things that exist in the cosmos. Togetherness is composed of distinction that is inseparable.

Is all this too abstract? Here is a concrete example of togetherness. Only in USA does Trump stands out hideous as the white-supremacist and separatist racist. This is because USA is USD, US of Differences. This USD is the only nation of togetherness of differences. Lincoln's Civil War would have been unthinkable in Europe that is a giant historical block of proud racism. Trump would be an unnoticeable "one of us" in Europe. The big uproars in USA themselves demonstrate that USA is the first world experiment in togetherness that has been tottering and working for over two centuries, German Jürgen Moltmann said, perhaps in envy.

Now, when togetherness the distinguishable-inseparable confronts head-on with separation distinguishable-as-separable, lethal tragedy erupts. Holy people hoard themselves as so distinct as to be separate from un-holy people. These people proudly call themselves "Pharisees the separatists". These separatist holy people hate being disturbed by another supposedly holy person, who is so different from un-holy people that he embraces those unholy people.

Doesn't "holy" itself mean separate? Separatist holiness is a simple tautology. Holiness as separate never likes joining holiness so contradictory as to be so mixed-up and so dirty unclean. Hatred of being polluted by such inclusive holiness finally exploded in "holy separate people" crucifying "holy embracing loneman", Jesus Christ who is the sole anointed one with holy love that is absolutely inclusive.

So, separative holiness kills embracing holiness; that is the fatal tragedy of holiness against holiness. What happened next is quite incredible. This event fully shows the embracing holiness as radically embracing all to the bitterest end, even embracing mortal hatred. The embracing so embraces the separative as to let the separative kill the embracing. That is already incredible enough. Even more stunning is this. After dying the most painful and abject death on the cross, the embracing embraces this death and rises up back to life. The embracing is the undying phoenix rising out of its own ashes. This special phoenix is rightly called "love" that embraces even the deathly hatred of it.

It is thus that such dying of undying love is applauded as strong as death (Song of Songs 8:6), because love is stronger than death that is its enemy. Such is the Good News of the cosmos, consisting in showing how the distinguishable- 
inseparable is life stronger than the killing of it by distinguishable-as-separable. Loving togetherness of life is stronger than its separation by death. This is the unshakable basis on which our unshakable hope for the future is anchored. This anchor is our conviction that is faith our rock of ages. This is the drama of love unconquerable; togetherness is strong indeed. It is time logic ultimate and cosmic.

Another sort of togetherness no less radical is that the all-powerful becomes all-powerless, almighty God become a helpless baby to lie in the bosom of human parents who are themselves so fragile. Such happening of all-powerful as allpowerless is called "Christmas". Thus we encounter the Good Friday of gory death of our Savior on the cross, the Easter of silently powerful resurrection no one can stop, and their origin Christmas the embracing of the all-powerless by the all-powerful. God all-powerful accepts us ugly and helpless, and becomes an all-powerless baby to snuggle into our parental bosom for us so helpless to care for. Such is Christmas that is simply amazing.

The year-end begins the year-beginning to make jolly holidays. Holidays are holy days totally awesome. The holy is our Parent all-powerful who yet entrusts himself as an all-helpless baby into our parental bosoms to care for, to raise him up into our Savior. "Immanuel God-with-us" is the name of the inter-baby reciprocity. Infinite baby-warmth pervades to enwrap us as I baby-care for my neighbors one by one. The Baby-Kingdom reigns. All these surprises chant the music of royal pomp and circumstance that perfumes the cosmos to enwrap and ennoble us personally, who in turn are helpless babies to our all-powerful Parent our Creator. All this is our time logic pushing ahead, ever.

Christmas, Good Friday, and Easter are the three pivots of vast togetherness that is cosmic love. This love universal conquers all hatred into happy personal existence, even through the death of such love that is as tender as a tender baby. These three pivots detail how "with us" God almighty is. This "with us" is amazingly revolutionary, accepting abominations and turning them upside down (Acts 17:6). Detailing them stuns us indeed.

God in his Son accepts even our hatred, allowing us to kill him, and then reverses it, quietly coming back alive to make us-who hate him-alive. God accepts our prideful "righteousness" by offering lambs to ennoble ourselves (Todo, 1965), and warmly covers us by offering himself as a lamb to cover our pride and our sin-to save us. Concrete details follow here, all so stunning.

Our offerings of our dearest first-borns, to cruel Moloch to appease him, was accepted and reversed into God offering his Only Son to die miserably, to woo us back into his fold of family love. Foul sexual acts to copulate with Baals are accepted and reversed into Christ's life-giving love of his bride his church. Shocking cannibalism is accepted and reversed into the victim-Jesus pursuing us to munch on him and drink his blood (John 6:54).

Even death and hell are accepted on the deathly cross to turn love as deathstrong and as hell-ferocious (Songs 8:6), to round them up into instruments of love. Love has done so in its cross and its resurrection. Such acceptances and re- 
versals show how revolutionary God is "with us" to love us continually until he saves us. Such is divine love that never lets us go, as it lets us be-no matter what. Death and its beyond show how radical such stubborn love is.

In addition, such "with us" of togetherness is amazingly fertile, forever bubbling up with unending varieties of resounding togetherness. These varieties sing "music" that chants together unlimited, forever open and alive. Music is time logic laughing together on and on, as it does eternally open into amazing varieties without ceasing. Such riches are so overwhelming as to make us reel into ecstasy. This is the fertility of time logic all so concrete on the move.

"Is the concrete the same as actuality?" A good point you raised, pal. The concrete is related to the actual but different from actual. For example, myths are actual but not (yet) concrete, waiting to turn concrete by us. Let me explain. Myths not concrete are actually dreamed up and planned on. Myths not concrete are what pull us ahead into our mythical "better tomorrows". Our tomorrow is our hoped-for myth since we cannot know it for sure, and things unknown are our myths.

Our dreams of myths remain just that, a puff of dreams buried in stacks of papers and cards. These myths require us; in fact urge us, to make them concrete. Our dreams of myths are actual and not (yet) concrete. Our dreamed-up myths are on their way to being concretized through our struggling engagements. This is our daily business that we pursue one day after another.

Our ongoing push-ahead is all-open and all-unknown, to go into the tomorrow that keeps coming over us. Concretization of actuality is coherent cohesion into actuality here now today. The concrete is thus our constant joy-struggles of open coherence from today to tomorrow, on and on. "Open" is unlimited surprising; "coherence" is concrete consolidation. "Open coherence" is time logic on the concrete go. Such is time logic on the move that constitutes our living days constantly composing concrete things.

Erasmus powerfully describes how cohesion of elements composes solid existence, from the stars through the stones all the way to plants and animals and human beings. Among human beings are distributed variously different capabilities, incomplete in each alone, to induce human beings into gathering together to complement and cooperate for common solidification and defense (Erasmus, 1521). Cohesion concretizes into existence. Now, this existential cohesion naturally implicates our pleasant duty to communal amity of mutual assistance. This is proper time logic on the move ahead.

In contrast, contentious divisiveness induces death of any existence, be it a person, a community, or a nation. The house divided against itself cannot stand. The nation divided against itself cannot survive. It is hate that divides, and it is dividing that kills. Divisive tyranny of any sort is doomed, sooner than later. First, the rich oppress the poor, and then the rich rise up against the rich, and the rich and the poor die in droves in contentious hatred, the poor forced to, the rich being rich enough to initiate the hate-dividing to kill, in order to kill all other peoples, and then killing themselves-all in hatred that divides. 
The people would spontaneously rise up to protest such money inter-butchery. They are usually the poor who would not allow themselves to be oppressed to death, and so revolutions, often quite bloody, erupt often in history, as graphically displayed in the history of China as well as any history of any region elsewhere. Such revolutions are actual "democracy" so spontaneous.

Revolutions kill so many as they rise from the social below, at the base level of the people. Such killings and risings graphically demonstrate how we simply have to amicably cohere, to exist at all. Such coherence is so spontaneous that it is often incapable of being pre-planned. Who can plan a revolution? Revolution naturally erupts without rhyme or reason, to wit, totally open to factual contingency. Existential coherence is all-open.

\section{Open and Coherent}

In addition, time logic is in "open coherence". This phrase invites ridicules from a usual logician. "'Open coherence' is quite sloppy. 'Open' contradicts 'coherence'. 'Open' is not charted or defined”. This complaint is of course logically understandable, but it actually barks up a wrong tree. Two responses are in order, on "open" and then on "coherence", as follows.

To begin, "open" cannot be limited in any way. "Open" is in-finite, and so cannot be de-fined, to wit, confined to any conceptual frame, and so usual logic is all-powerless to handle "open". All usual logic can do then is to stop at the helpless indefinable pit, which is "open”. But such openness is precisely within the elements of time that goes on and on logically open infinitely, never finitely closed off. Moreover, wonder of wonders, such open-ended ongoing that is time is not arbitrary but "coherent"; time is never random "hit and run". Time is always sensible and coherent, while it is all open, unlimited. Such open coherence spells "time logic".

In fact, as time goes on openly, time coheres into sense. This is how time is time logic. History graphically shows how endless- "open"-the ongoing of happenings somehow coheres into a story-sense as their seemingly random stories are told. What is senseless-"sloppy"-in usual logic turns out perfectly sensible in time as time logic that is "open coherence". Let me repeat. All this describes time logic, time as logical and logic as open-coherent in time.

Interestingly, "open coherence" as "coherence" itself is the process-time is a process-of cohering, and cohering sticks-together, so as to concretize concrete things. Thus "coherence" is time's creative process of things concrete. Besides, since "open" is continual limitlessly, "open coherence" describes creatio continua, continual creation of things concrete. Time logic is the concrete logic of continual creation of concrete matters. Time as logical is time as divine creation because of its feature of "open coherence". Time logic is related to the logic of the divine, both alive and creative. Now, who would dare say that "open coherence" is logically sloppy?

At the same time, Christian divinity is beyond humanity fivefold. One, God my Parent who constantly creates me dies for me. Two, it is bad-I who kill him. Three, in my patricide, he hugs me tightly and softly, never letting me go. Four, 
when love gets serious, it is not pretty. Love gives all, and demands all! Given all is so sweet; demanded all is unbearably severe. Loving enemy who is intent to destroy me is love's one toughest of its many demands on the beloved.

Five, love is less often an agent than it is patient. Love suffers long, accepting the unacceptable, bearing what we cannot bear. Such stubborn forbearance, constantly receiving various insults and countless oppositions, will win out in the end, and all is well that ends well, however twisty the route to the end is. Love all-embracing, borne with all sorts of injuries and injustices, has the last word, and the "last" is time-notion. Love is time logic at its supreme heights.

This is why love is stronger than death its enemy, and more ferocious than hell its opposite, to climax Song of Songs 8:6 in praise of love. I can never get over this stupendous fact that hits me five ways as described above every single day, in fact, every single moment. All this open forbearance expresses time logic inside me to flood me with the deluge of creative love all over beyond me. Time logic is divine both on my part and on the part of the Beyond forever beyond me. Divinity is time logic par excellence.

Still, what is tragically beyond all my understanding is this. After Erasmus has powerfully argued for mutual amity as inherently creative of existence, against any hateful contention that kills all over, people still keep fighting in hatred. Behind Erasmus stands Mencius who argued tightly and heartfelt, and urgently, from unbearable co-pathos interpersonal to unbearable co-pathos governance of people. Since the days of Mencius, history in China has been drenched in battles bloodshed unlimited.

The moving and tight arguments of both Erasmus and Mencius should have long ago persuaded all people toward ubiquitous neighborly togetherness. Tragically, however, all histories in China and elsewhere tell of consistent and complete indifference among all peoples. This is a mystery totally beyond my wits. Greatly persuasive Mencius and Erasmus have produced great historic failures! This mystery points to the Beyond-human.

\section{Divinely Exchanging Logical}

The last point above, the failure of persuasive arguments, intimates this additional point on time logic. Time logic is in addition an exchange-logic beyond humanity, typified in the ultimate realm of religion. Being unable to resolve the mysteries of fighting despite its powerful dissuasions, we take flight beyond humanity. A powerful refrain is here. Its power can only be chanted in poetic format as follows.

"O what peace we often forfeit!

$\mathrm{O}$ what needless pain we bear!

All because we do not carry everything to God in prayer."

Jesus breaks down as we break down, 
to raise us up in his coming-back alive.

At once calm-joy comes

as I give up my all to my

Lord Jesus in Father God!

My all is given

for

His all given me.

It is fair, but it is much

more than fair because

His vast all is given for

my dust-bit of sorrows.

I am totally overwhelmed!

All this is vastly heavenly.

I'm weak shouting heartfelt.

Psalms 147:3 is a precious powerful verse singing! See also Psalms 129:3-6, another powerful song!

Now, in this divine context, you cannot say, "I hope, pray, and believe I'll see Jesus after I have lived my life". What do you mean you hope, pray, and believe to see Jesus? Do you hope, pray, and believe to breathe? Isn't it so silly? How could you breathe without Jesus? Jesus is my breathing. Jesus breathes me, talks me, and smiles me, to die me. I live not I, but Jesus lives me (not in me, as Galatians 2:20 says). I am as I am with Jesus, whenever I am or will be. As I never hope or believe my breathing but just breathe, so I never believe Jesus but I am just Jesus. As I breathe Jesus, I will die Jesus. If all this is false, then all my breathing is false, and all my doubts are false. Again, I am totally overwhelmed.

Pain cannot be mocked, however. Pain forever throbs; it comes over me, only to come again, as it carves itself timelessly into each split-second, one at a time, killing time. In contrast to pain, joy is stronger than deathly pain, and in joy time likewise vanishes; joy wipes out time. Everything stops, timeless, in joy. Both pain and joy are ecstatic, standing out of time.

"But time makes things concrete. Wiping out time wipes out things concrete". Good point you raised, pal. Well, it is joy that makes time, commands time, even to the point of wiping time out in joy-ecstasy-to make things concrete. Joy is the queen of the concrete to conquer pain timelessly throbbing through time. Joy incarnates time logic, while pain tries vainly to destroy time logic.

Meanwhile, "being overwhelmed" above described spells sheer joy, singing dancing, and jumping alive in pure poetry. Preface to Poetry Classic 詩序 puts the power of poetry as joy as the root and origin of life (Chu, 1971). "Poetry is where our mind and intention reach. Intention is in the heart and mind. When expressed in words, felt intention turns into poetry. Poetry is expressed heartfelt. 
Feeling overflows inside to form itself in words. Wording out is not enough, so we deeply sigh. Sighing is not enough, so we chant and sing. Chanting songs is not enough, so our hands dance with our feet tapping mightily, all unawares". This is joy all poetic, jumping logical. All this chants music-thinking, and music is the supreme art of time, one and only, rhythmic alive so poetic. Music is time logic at its ultimate. Music is time logic par excellence, dancing chanting without ceasing.

Thus it is that time logic consists in joy serene and secure, and cautiously and confidently optimistic. Religion of the Beyond-all calls joy repentance into salvation. Time calls it living history here now beyond here now. History retires back into the past to re-tire-put on new tires-ahead into the future, back and forth, ever on the go as time logic alive. This is the concrete bodily lived and story-told in joy. Time logic is incarnated in body thinking, concrete thinking, story thinking, and music thinking, throbbing alive through time. Time logic is history of joy.

Thus time logic is logic-dynamics fivefold as follows. Here, one of these dynamics involves all other dynamics. First, time logic is logic of concrescence grown-together into concrete logic that bundles matters into senses (MerriamWebster's Collegiate Dictionary, 2008; Wu, 1998, 2001). Secondly, time logic is synthetic logic, as " $7+5$ " synthesizes itself into " 12 " that cannot be deduced from " 7 " or " 5 ", as Kant noted. Thirdly, time logic is story thinking. By means of telling a story, we open out to all happenings whatever, and then organize them into a coherent sense. Story-logic is thus an amazing feat of time logic.

Fourth, time logic is history thinking. History collects facts and this collection of facts is analytically stranger than fiction humanly designed. History opens out from the past into the uncharted future. Fifthly, time logic is exchange logic to compose joy rhythmic. Typically, I exchange my lousy troubles with the Beyondme who gladly accepts my sorrows as my Parents do. This exchange quite often results in music that chants the joy of living.

Sea-music (such as chanted by Elgar and Vaughn-Williams) shows how vastly oceanic the concrete is, not quite private and individualistic nor is it impersonally indifferent, but gently personal to embrace, in person, each of us as "I".

Listen to Edward Elgar, "Sea Pictures" in CD 5 in "Edward Elgar: The Collector's Edition", EMI, 30 CDs. Listen also to Ralph Vaughan Williams, "A Sea Symphony" in CD 1 in "Vaughan Williams: The Collector's Edition", EMI, 30 CDs. They cleanse us and put us at home. The oceanic concrete is somehow familiar as our relatives and families but not engulfing us hopelessly as in a huge cosmopolitan city. Mother Nature is an ocean vastly moistening us yet not drenching us all wet, much less drowning us in a helpless deluge. In the oceanic concrete, things are vastly musical and primal. The concrete is primal musical, the primordial music yet to sing out definite music. To music we now turn.

\section{Music the Art of Time}

Music is concrete and sensible, to resonate to spread all over in time. Music is 
the art of time logic par excellence. Music deepens the sheer presence of the present, while it continues to move on, to move us its listeners on to the next moment, and then on to its next, and on, deeply sighing. Presence and moving are inter-involved, so as to run into each other. Their moving presence of music presents time logic.

Music in this stop-and-go way incarnates time logic. Music is the felt logic of mathematics, as mathematics is the music deeply felt. All this feeling logic rhymes in pulses to enliven logic. Time logic on the move actualizes how time logic progresses on and on, heartfelt as sheer music. Music is the symbol of mathematics, and mathematics is musical symbol, and both are rhythm of time logic deeply felt.

It is thus that, importantly, if there is no feeling, there is no music. Music is sheer feeling-in-form in the making. Feeling is the sheerness of the presence of the present; this is quite important. Music stops us-Wow! Music stops to stops us!-from frivolously sliding from one moment to the next. The sheer presence of the present forbids frivolity of prodigal waste of time, which is the essence of life. That stoppage makes sheerness of the presence. That depth of sheerness is called "feeling". So, music is time logic in feeling, for, thanks to music, feeling makes sense, and making sense is "logic" of time.

In addition, the music of Haydn and Bruckner, as well as Couperin and Bach, is steady throughout the moving sounds; their steady music steadies me the intensive listener. Their many techniques produce steady music-repetition, parallelism, variation, packing by echoing one melody against another, antiphony, structural fugues and decorations, etc. These "techniques" ingeniously actualizes the "logic" of time. Depths of sheer presence steady the life of the hearer who dips in time-moving. Time logic moves to steady our life in time. Music deepens and steadies.

A third element in music is frivolity. No music is without it; take it away, and music dies away. "Serious music" is anathema to music. Frivolity plays (with) music to make music jumping alive, opening out into new melody-horizons one after the surprising other. Frivolity is heresy in music to break down musical order and decency that deadens, as order tends to death in decency so straight. Straight decency kills.

Frivolity implicates being casually natural. Any pounding of a hammer and any silly barking of a dog spontaneously compose rhythms that are the primal music of things to originate composing human music. Frivolity is one most fascinating aspect of time logic. Frivolity is the creative power of time logic quite unexpected, to initiate novel dimensions of the reasonable logic of time.

Moreover, precisely because frivolity is out of expected order, we cannot plan or design it. Frivolity comes all of a sudden when we are relaxed, thinking of nothing as we look casually askance on things. Frivolity happens at side glance, in the corner of the eye, and can never be an agenda on a conference table. All "serious musicians" are daunted by frivolous aspect of music-Heifetz, Furtwängler, Menuhin. Impish Mozart is their enormous challenge. Only spontaneous Fritz 
Kreisler devil-may-care barely approaches it.

But precisely because of being unable to pre-plan, frivolity provides free reins to astounding varieties of creativity into new music and performing ingenuity, all so enjoyable to composers, performers, and audience. Frivolous creation of music is indescribable, but identical Violin Concerto in G major by Haydn is played all differently by Menuhin, Hadelich, and Guglielmo. Haydn's String Quartets create two all-distinct worlds as played by two quartets.

Yehudi Menuhin's performance is recorded under the EMI label. Augustin Hadelich's is recorded under the Naxos label. Frederico Gugulielmo's is recorded under the Brilliant label. Haydn's String Quartets are played by Buchberger Quartet under the Brilliant label, and the Angeles Quartet under the Philips label. John McCabe (Decca) creates a world differing from Jenö Jandó's (Naxos), both by performing Haydn's Piano Sonatas. Beethoven, Mozart, Schubert, and Schumann are subjects of their countless performances. China's literature composes music.

Frivolity enthralls. Each of "presence, stability, and frivolity" of music disturbs the other to enhance their bewildering fascinations that are music bouncing alive, in creation and enactment-as-creation of time logic. All frivolity exists in "serious thinking" to enchant and enhance thinking. Thinking turned frivolous is thinking turned profound and jumping alive, while thinking keeps all its profound seriousness. Frivolity deepens the seriousness of thinking. Such is the logic of time-in frivolity.

\section{Logicizing}

So many Piano Sonatas of Haydn "argue" clearer and tighter toward later Sonatas for one surprising musical point after another, into beauty-tapestry. All music both classical and popular organizes sounds logically to "argue" for a point in beauty alive through time. To "organize", "argue", "into", and "beauty-tapestry" are music-activities of time logic. Music is time logic developing and arguing into itself.

As time continues to go on, it sings as it flows all over in frivolous freedom so voluptuous. In all their freedom, ideas inevitably breathe into us, as ideas come over us as inspiration in-breathed into us. Freedom is fresh. I cannot help but capture these ideas so fresh and enticing. I am inspired and elated as I am enriched and enthralled by these free ideas that freely come over me. I capture these exciting ideas in two ways.

First, I write down-de-scribe-these ideas. Writing down ideas clarifies ideas, to turn them no longer vague and uncertain. These ideas are now definitely put on paper, certain and fixed to gloat over anytime. And then, I can arrange these ideas in front and make them systematically orderly. Thirdly, I bring these ideas into dialogue with others, so that these ideas can be refashioned, corrected, improved on, and added on with new ideas and new ways of systematizing them. These two ways in three steps are intimately involved; one goes on with the others to enrich one another. Thinking is dialogical in a deep interper- 
sonal sense.

Dialogues can happen by reading books written by someone else than me, to be criticized by me. Or else I can write my own books, and come back later to my own original pages and revise them, or of course by discussing ideas in my books orally or by letters with fellow thinkers. All such thinking as various dialogues takes place in time. Creation of novel ideas and their continual betterment in reciprocal critiques describe thinking that consists in time logic as this. Time logic logicizes, of course.

But then, here comes a glitch. Men have been at war (personally, communally, and nationally) since the world began. Erasmus calls it insane anti-nature, Christians call it devil, and Freud calls it death-wish. But name-calling solves no problem of why wars exist always, though quite anti-natural as Erasmus (1521) powerfully and unconditionally argues against all wars.

But the more persuasively he argues against war, the deeper the illogical absurdity of war bites into us. This war-dissuasion while continuing to battle is quite an illogic stubbornly staying at a corner of time logic. This illogic in time logic stares at us in the face, and refuses to leave us, as long as we continue to be brutally at war, without rhyme or reason. War is an illogic in time logic.

"How is war an illogic in time logic?" A good question you raised, pal. I mean this. History is timed logic. Men have been fighting and killing one another since the world began - that is a fact of timed history. Erasmus argues that killing is anti-nature-that has also happened as timed history. These two timed histories collide, and so time logic shows its actual illogic in history that is time-logic itself.

Meanwhile, we know that all is well that ends well, and our life is punctured by these ends-well. But all can still be well that may not end as well as we wish. All depends on how we "stick it out" in our living days. We are the captain of our destiny; time is ours. Ultimately, this is the ethical implication of time logic. Time logic is the ruler within us ourselves, and we cannot avoid turning responsible for our own time allotted us to manage, and we must if we love to live on.

The ethics of time cannot help but remind us again of the historic Chinese calligraphy; it is Chinese thinking dancing alive. This historic calligraphy in the long history of China loudly sings such time logic, continually throughout world history. This is another spin-off from the illogic of time logic. How would I be responsible for my living time while we are continually at war? Can my life be a series of my own calligraphy of life, despite all things to the contrary?

They are all sired by the calligraphy-sage 王羲之 (Si-Chi Wang) and developed their own distinct styles, to set their various standards for subsequent calligraphers. Such is the voluptuous overflow of writing genius expressing an all-out freedom of thinking. Thinking is now a set standard because of its free voluptuous development. This free thinking-development is part of time logic.

I jot down what happened today in my diary, each day as it ends. I thereby review what has been done, what has failed, and plan for tomorrow accordingly. I do so every single day, back and forth, to and fro, and my days make progress slowly, inch by inch. It is in this way inching ahead that time logic actualizes it- 
self in my days, on and on, world without end.

In such retrospective forwarding, time logic makes me a homo viator who is a person on the way, despite our continual wars inter-butchering. It is thus that time logic always begins and has no end, ever bubbling ever various, embracing all to let all be, what will be as it will be self-so, all-comprehensive. Time logic is ever alive in such way as this. Time logic is an always-dynamics that is stubbornly logical through persistent illogic. Time logic is the queen of all thinking and all happenings.

\section{References}

Buber, M. (1958). I and Thou. New York: Scriber Classics.

Buttrich, G. A. (1962). The Interpreter's Dictionary of the Bible (pp. 869-896). Nashville, TN: Abingdon Press.

Chu, R. (1971). Poetry Classification. Taipei: Business Publishers.

Erasmus, D. (1521). The Complaint of Peace: Translated from the Querela Pacis (A.D. 1521). Chicago: Open Court, 1917.

Frankl, V. E. (1984). Man's Search for Meaning: An Introduction to Logotherapy. New York: Simon \& Schuster.

Friedman, M., \& Schilpp, A. (1957). The Philosophy of Martin Buber (pp. 41, 720). La Salle, IL: Open Court.

Howatson, M. C. (1991). The Oxford Companion to Classical Literature. New York: Oxford.

Kant, I. (2007). The Critique of Pure Reason. New York: Penguin.

Merriam-Webster's Collegiate Dictionary, Eleventh Edition, 2008, pp. 615.

Plato (2008). The Republic. Translated by N. Jowett, New York, NY: Digiread.com Publishing.

Plato (1941). Republic 514a-521b.

Reese, W. L. (1999). Dictionary of Philosophy and Religion (pp. 208-209).

Spicker, S. F. (1970). The Philosophy of the Body (pp. 90-97). Chicago, IL: Quadrangle.

Stewart, J. A., \& Levy, G. R. (1960). The Myths of Plato. Carbondale, IL: Southern Illinois University Press.

Plato (1941) The Republic of Plato (pp. 227-235). Translated by Francis MacDonald Cornford, Oxford: Oxford University Press.

Tillich, P. (1968). The Courage to Be. New Haven, CT: Yale University Press.

Todo, A. (1965). Etymological Dictionary of Chinese Characters (p. 592). Tokyo: Gakutosha.

Schilpp, P. A. (1991). The Philosophy of Alfred North Whitehead. La Salle, IL: Open Court.

Schilpp, P. A. (1951). The Philosophy of Alfred North Whitehead. New York: Tudor Publishing Company.

Wu, K. M. (1988). On the "Logic" of Togetherness: A Cultural Hermeneutic. Leiden: Brill.

Wu, K. M. (2001). On Metaphoring: A Cultural Hermeneutic. Leiden: Brill. 
Submit or recommend next manuscript to SCIRP and we will provide best service for you:

Accepting pre-submission inquiries through Email, Facebook, LinkedIn, Twitter, etc. A wide selection of journals (inclusive of 9 subjects, more than 200 journals)

Providing 24-hour high-quality service

User-friendly online submission system

Fair and swift peer-review system

Efficient typesetting and proofreading procedure

Display of the result of downloads and visits, as well as the number of cited articles Maximum dissemination of your research work

Submit your manuscript at: http://papersubmission.scirp.org/

Or contact ojpp@scirp.org 